\title{
STUDI TIPOLOGI KARYA DESAIN ARSITEK REMMENT KOOLHAS
}

\author{
Susana M. Suratama ${ }^{1}$, Dian E. W. Johannis ${ }^{2}$
}

\begin{abstract}
Abstrak:
Proses seorang arsitek dalam merancang karya-karya desainnya, tentulah didasari teori atau konsep yang kuat. Dan dari teori, metode dan bagaimana mengaplikasikannya dalam rancangan itu dapat dilihat kekhususan atau keunikan si arsitek dibandingkan dengan arsitek lainnya.

Remment Koolhaas, seorang theorist, urbanist, kritikus dan arsitek Belanda, seringkali berbicara mengenai perubahan budaya pada masyarakat kota. Pengaruh kapitalisme dan liberalisme terhadap kehidupan perkotaan secara implisit menjadi sasaran kritik-kritiknya. Kritiknya, melalui berbagai karya buku, menjadi sindiran terhadap kehidupan masyarakat kota itu sendiri. Koolhaas mendapat julukan sebagai seorang yang cynical. Kritik-kritik Koolhaas tidak hanya berhenti pada tulisan saja. Hal tersebut berlanjut dalam desain karya-karya arsitekturnya sebagai “content” yang terkamuflasekan, tetap sebagai sindiran terhadap kehidupan masyarakat kota itu sendiri.

Penelitian ini betujuan untuk mendapatkan Tipologi dari Karya Desain Arsitek Remment Koolhaas berupa Teori/Konsep, Metode, dan Aplikasi Desain yang bermanfaat bagi Preseden untuk kegiatan pendidikan dan profesional bidang arsitektur

Penelitian ini menggunakan metode content analysis dengan mempelajari pemikiran, teori/konsep, metode, dan aplikasi desain arsitek Remment Koolhas lewat literatur yang terbagi dalam : Kelompok I, berupa karya-karya teoritis dari Remment Koolhas dan Kelompok II, berupa karya-karya arsitektural.

Hasil penelitian menunjukkan Koolhaas sendiri memasukkan dan melakukan kamuflase terhadap "prinsip-prinsip pemikirannya" dalam desain, yang disebut "content camouflage". Dengan menggunakan 3 (tiga) metode yang sering digunakan yaitu : 1) Augmented space ; 2) Cross programming ; dan 3) Programmed-free programmed space. Metode-metode ini terlihat sangat konsisten digunakan Remment Koolhas dalam karya-karya desain arsitekturnya.
\end{abstract}

Kata kunci : Tipologi, Konsep, Metode, Aplikasi, Preseden Arsitektur.

\section{PENDAHULUAN}

Dilahirkan di Rotterdam pada 17 November 1944 dengan nama Remment Koolhaas. Era akhir perang dunia ke-2 mengakibatkan terjadinya perubahan-perubahan cepat pada banyak hal di dunia. Kenyataan ini berlanjut saat Koolhaas muda mengikuti ayahnya untuk bertugas di Indonesia pada tahun 1952. Ayah Koolhaas sendiri seorang kritikus film dan jurnalis koran beraliran kiri yang sejak awal mendukung kemerdekaan Indonesia melalui tulisan-tulisannya (dalam Guardian, 2006). Hal tersebut yang membuat ayah Koolhaas diterima di Indonesia, yang baru saja merdeka, untuk bertugas sebagai Direktur Institut Kebudayaan selama empat tahun. Koolhaas sendiri berpendapat bahwa masa-masa itu ia sungguh merasa hidup sebagai orang Asia. "It was a very important age for me. And I really lived as an Asian." (dalam Guardian, 2006). 
Setelah kembali ke Belanda, koolhaas sempat mendapat pendidikan di Dutch Film Academy dalam bidang penulisan naskah film. Kemudian sempat bekerja pula sebagai jurnalis di "Haagse Post". Tahun 1968 merupakan persentuhan awalnya dengan dunia arsitektur saat Koolhaas memutuskan bersekolah di Architectural Association School of Architecture, London. Pada tahun 1972 Koolhaas melanjutkan pendidikan arsitekturnya di Cornel University Ithaca dan Institute for Architecture and Urban Design New York. Selama di New York, Koolhaas berada dalam bimbingan Peter Eisenman, seorang arsitek yang intensif di bidang teori kritis dan "critical Architecture" (Heynen, 2004). Eisenman adalah orang yang mendorong Koolhaas meluncurkan buku pertamanya, "Delirious New York".

Sebuah pernyataan dari kritikus Inggris, Charles Jencks: "The writing of 'Delirious New York'was famous before Rem's architecture, and it was better than his architecture." (Jencks dalam Lubow, 2000) cukup menggambarkan bagaimana Rem Koolhaas sebagai seorang penulis mampu memberikan kontribusi positif dan produktif dalam ranah teori arsitektur. Koolhaas juga memiliki kemampuan untuk berbicara dalam tiga bahasa secara simultan: bahasa arsitektur, bahasa klien (populer) dan bahasa jurnalis. Di antara sekian banyak karya tulisnya, dari artikel hingga buku, terdapat beberapa yang cukup signifikan menandai posisinya sebagai seorang theorist.

"Delirious New York" merupakan buku pertamanya yang diterbitkan tahun 1978 menandai kemampuan serta minatnya yang sangat kuat terhadap urbanism. Buku ini mampu memberi pengaruh yang sangat kuat terhadap paradigma new urbanism.

"S， M， L， XL" merupakan karya selanjutnya, diterbitkan tahun 1995, yang semakin memperlebar pengaruh Koolhaas dalam ranah teori. Buku ini berisi tentang beberapa proyek OMA-Koolhaas, dengan banyak essai di antaranya, yang terstruktur dengan rapi berdasar pada skala proyeknya. Buku ini banyak berbicara mengenai skala.
"Project on the City" merupakan proyek Koolhaas sebagai Profesor di Harvard Design School. Proyek ini menghasilkan 3 (tiga) buku utama, yaitu: "Mutations" (2001), "The Harvard Design School Guide to Shopping" (2002) dan "The Great Leap Forward" (2002). Proyek ini merupakan sebuah penelitian yang banyak menyoroti mengenai perubahanperubahan budaya di perkotaan.

"Content" (2003) merupakan buku terakhir yang menjadi rujukan penelitian ini. Buku ini sedikit berbeda dari buku-buku sebelumnya. Buku ini lebih menggambarkan bagaimana OMA berbicara mengenai OMA sendiri. Sebuah bentuk dialog yang berbeda dari karya-karya sebelumnya. Format buku yang lebih menyerupai majalah ini merupakan bentuk "branding" OMA. Melihat keragaman bentuk dan kepadatan informasi yang ingin disampaikan, buku ini menegaskan salah satu pernyataan Koolhaas, juga dalam buku ini, "Never mind the style... Feel the quality" (Koolhaas, 2003).

Desain karya arsitektur dan proses perkembangannya sampai saat ini, sering dilihat dalam dua sudut pandangan yang berbeda. Pandangan pertama, objek arsitektural dianggap sebagai sesuatu yang unik dan orisinal, karena merupakan ekspresi yang dipikirkan oleh si arsitek. Dengan demikian seharusnya tidak mungkin ada dua objek arsitektural yang persis sama, sekalipun dibuat oleh orang yang sama. Pandangan kedua, mengatakan sebaliknya, bahwa objek-objek arsitektural dapat memiliki nilai yang sama dengan objek lain yang dihasilkan dari sebuah aktivitas yang bersifat repetitif (berulang kali) dan bahkan sengaja dibuat agar untuk seterusnya dapat diulangi lagi. Artinya, sebuah objek arsitektural bukan saja menghasilkan sebuah pengulangan, melainkan juga dihasilkan dari sebuah pengulangan. Dan tindak lanjut dari konsep pengulangan ini, didapat tipologi yang dapat diartikan sebagai sebuah aktivitas klasifikasi dan pengelompokan. Tipologi merupakan konsep untuk mendes- 
kripsikan kelompok objek berdasarkan atas kesamaan sifat-sifat dasar, dengan cara memilah atau mengklasifikasikan keragaman bentuk dan kesamaan jenis.

Penelitian ini lebih merujuk kepada pandangan kedua sebagai acuan. Dengan asumsi dalam proses seorang arsitek dalam merancang karya-karya desainnya, tentulah didasari teori atau konsep yang kuat. Dan dari teori, metode dan bagaimana mengaplikasikannya dalam rancangan itu dapat dilihat kekhususan atau keunikan si arsitek dibandingkan dengan arsitek lainnya.

Tujuan penelitian ini adalah untuk menganalisis Karya-karya desain arsitek Remment Koolhas untuk mendapatkan: konsep \& tipe, level tipologikal, dan proses dari tipe. Tujuannya adalah untuk mendapatkan 1). metode perancangan yang telah ada; 2). tipe dari proyek bangunan yang telah ada sebelumnya; 3 ). functional typologies dari tipe yang telah ada sebelumnya, dan disesuaikan dengan desain yang baru.

Manfaat dari penelitian adalah ini :

1.Manfaat teoritis, yaitu diharapkan dari penelitian ini dapat memberikan sumbangan untuk memperkaya teori-teori tipologi karya arsitektur sebagai perwujudan dari proses kreatifitas.

2.Dalam lingkup praksis penelitian ini diharapkan dapat memberikan gambaran tipologi karya desain arsitek Remment Koolhas. Gambaran keragaman tipologi karya desain arsitektur Remment Koolhas dapat memperkaya pemahaman yang berkaitan dengan fenomena yang mempengaruhinya.

\section{METODE PENELITIAN}

\section{Paradigma Rasionalistik dan Metode Content Analysis}

Penelitian ini menggunakan paradigma rasionalistik dengan metode content analysis dengan mempelajari pemikiran konsep desain arsitek Remment Koolhaslewat literatur maka bisa didapatkan dua bentuk yaitu pemikiran dan informasi teks karya-karya arsitekturnya.
Metoda content analysis dengan studi intertekstual yang digunakan merupakan cara untuk memperkuat validasi pada saat melakukan interpretasi data dan kesimpulan yang diambil oleh peneliti. Di dalam content analysis, peneliti dapat menggambarkan konsep tertentu, dapat diperbandingkan antara satu buku dengan buku lainnya (intertekstual) untuk melihat kasus tertentu, dan melihat sebab akibat, perbandingan, korelasi, termasuk perkembangannya. Nawawi (2005) dalam Alhamdani (2010) berpendapat bahwa Content analysis termasuk dalam metoda deskriptif.

Hostly (dalam muhadjir, 1998) mengemukakan lima ciri content analysis. Pertama, teks perlu diproses dengan aturan dan prosedur yang dirancang. Kedua, teks diproses secara sistematis, data mana yang tidak termasuk kategori dan data mana yang termasuk dalam kategori. Ketiga, proses menganalisa tersebut harus mengarah ke pemberian sumbangan pada teori, ada relevansi teoritiknya. Keempat, proses analisis mendasarkan pada deskripsi yang dimanifestasikan. Kelima bagaimanapun Content Analysis haruslah menggunakan teknikteknik kuantitatif.

Langkah pertama yang dilakukan dalam analisis menurut Nazir (2003) dalam Harisah (2005:50) adalah membagi data atas kelompokkelompok atau kategori-kategori. Kategori ini berupa pemikiran dalam bentuk teks maupun karya desain. Langkah Kedua adalah menggunakan content analysis untuk menganalisis isi teks-teks yang ada dan menemukan korelasi dan ketidakkorelasiannya menggunakan parameter tertentu.

Jadi penelitian content analysis menuntut teknik penelitian untuk menghasilkan inferensi terhadap data teks dan simbolik, yang dapat diulangi dan valid. Dimana analisis berbentuk dokumen dan teks yang berupaya menangkap isi menurut kategori yang sudah ditetapkan, dengan cara sistematis dan dapat diulang-ulang sehingga penggunaan prosedur penghitungan 
dan perekaman yang objektif dan sistematik untuk menghasilkan deskripsi tentang isi simbolik dari sebuah teks.

Pemahaman konteks dalam suatu teks tertulis sangat diperlukan dalam rangka menganalisis isi dari suatu teks, dan hal ini dilakukan dengan melalui penafsiran atau interpretasi. Untuk menghindari dan tidak terjebak dalam subjektifitas maka perlu dipahami mengenai prinsip pemahaman penafsiran atau interpretasi. Sumarlan (2003) dalam Harisah (2005) mengemukakan empat prinsip penafsiran wacana yang akan dijadikan dasar dalam penelitian, sebagai berikut :

1.Prinsip Penafsiran Personal.

Pembaca juga sekaligus penganalisis wacana harus mengetahui secara pasti orang yang terlibat (pelibat wacana) dalam wacana. Ini dapat dlakukan dengan mengetahui latarbelakang pelibat wacana, peranannya, hubungan antar pelibat dan konstribusinya dalam menentukan alur wacana.

2.Prinsip Penafsiran Lokasional. Prinsip ini berkaitan dengan penafsiran tempat atau lokasi terjadinya suatu situasi (keadaan, peristiwa, dan proses) dalam rangka memahami suatu wacana.

3.Prinsip Penafsiran Temporal. Prinsip ini berkaitan dengan waktu terjadinya wacana (teks) dan diperlukan agar tidak kehilangan orientasi dalam memahami teks atau urutanurutan peristiwa dalam teks pada saat pemikiran-pemikiran dalam teks tersebut dikemukakan.

4.Prinsip Penafsiran Analogi. Dalam berbagai teks terkadang terdapat kata yang bisa menimbulkan penafsiran ganda, karena itu untuk memahaminya diperlukan pemahaman teks yang mendahului atau mengikutinya sehingga dapat dipahami maknanya dengan melihat teks secara keseluruhan.

\section{Cara Penelitian}

\section{Bahan Penelitian}

Bahan yang digunakan dalam penelitian ini adalah teks (tulisan, gambar, dan foto-foto) dari buku dan tulisan di internet. Bahan yang digunakan dikelompokkan dalam dua kelompok amatan :

a. Kelompok I, berupa karya-karya teoritis dari Remment Koolhas yang diambil secara purposive.

b.Kelompok II, berupa karya-karya arsitektural yang juga dipilih secara purposive.

Bahan-bahan berupa teori-teori, pendapat ataupun kritik mengenai konsep desain arsitek Remment Koolhas yang kemudian diambil esensi pikiran-pikirannya, dikelompokkan, disistimatiskan sehingga tersusun konsepnya. Untuk mengetahui aras teori, konsep dan prinsip-prinsip perancangan maka didasarkan pada pemahaman mengenai teori, konsep, dan prinsip-prinsip dan metode perancangan itu sendiri yang di verifikasi dalam karya-karya arsitekturnya.

\section{Pemilihan Sampel}

Pemilihan sampel dalam penelitian ini dilakukan secara purposive. Menurut Mardalis (1999) dalam Harisah (2005), penggunaan cara purposive dilakukan dengan maksud tertentu atau dilakukan dengan sengaja dan dilakukan bila karakteristik populasi sudah diketahui sebelumnya. Sedangkan Marzuki (2000) dalam Harisah (2005) pengambilan sampel dengan cara purposive dapat dilakukan dengan syarat sampel yang diambil harus merupakan representasi dari populasi. Selain itu informasi yang mendahului tentang keadaan populasi sudah diketahui benar dan tidak perlu diragukan lagi

Pengambilan sampel pada kelompok I untuk Konsep pemikiran yang akan dianalisis isinya didasarkan pada kriteria-kriteria :

a.Pemikiran tersebut merupakan pemikiran utama dari Remment Koolhas yang ditentukan dengan mempertimbangkan banyaknya penggunaan pemikiran tersebut dalam membahas karya-karya teoritis maupun arsitekturalnya

b.Pemikiran tersebut dapat memberikan konstribusi dalam melihat perkembangan 


\section{1 | JUTEKS Jurnal Teknik Sipil Volume 2 Nomor 2 Oktober 2017}

konsep desain arsitek Remment Koolhas sendiri sehingga gambaran mengenai perkembangan konsep desain arsitektur Remment Koolhas dapat diketahui dengan jelas.

Pemilihan sampel pada kelompok II berupa karya arsitektural Remment Koolhas dipilih dengan beberapa pertimbangan :

a.Pemilihan kasus berupa karya-karya arsitektural yang dimana Remment Koolhas merupakan prinsipal arsitek sehingga diharapkan dapat menggambarkan keadaan sebenarnya dan bukan direkayasa untuk mendukung kesimpulan tertentu.

b.Karya-karya tersebut berupa bangunanbangunan dengan fungsi yang bervariasi dan lokasi yang berbeda dengan mempertimbangkan periode waktu karya arsitektural Remment Koolhas sehingga dapat secara jelas menggambarkan perkembangan konsep desainnya.

c. Karya-karya arsitektur yang dipilih adalah karya-karya yang mendapatkan apresiasi, baik dalam bentuk penghargaanpenghargaan, statement arsitek maupun pendapat kritikus bahwa karya tersebut dapat mewakili konsep desain dari arsitek Remment Koolhas.

\section{Analisis Data}

Analisis berdasarkan hasil objek karya desain arsitektur dengan melakukan prinsip penafsiran wacana terhadap objek-objek yang didapat.

Analisis dilanjutkan dengan mencari hubungan antara konsep-konsep dalam upaya untuk mengembangkan suatu konstruksi teoritis dengan cara constant comparative method, dimana fokus penelitian diidentifikasi. Deskripsi, analisis, dan perbandingan untuk dapat mengembangkan kerangka konseptual menuju teori.

Langkah-langkah yang dilakukan pada tahap constant comparative method yang digunakan pada penelitian ini adalah :

1.Pengumpulan data mengenai karya arsitektur Remment Koolhas.
2.Menemukan issue dari hasil penelusuran pustaka, kemudian dikategorikan.

3. Kumpulan data yang dikategori dijadikan sebagai obyek penelitian untuk kemudian mengetahui berbagai dimensi dari kategori.

4.Menguraikan dan menjabarkan melalui analisis kategori yang diselidiki untuk mendiskripsikan dan memahami semua aspek yang terdapat dalam data sambil menelusuri dan mencari hal-hal baru.

5.Mengolah data dan model yang muncul untuk menemukan proses dan hubungan dari masing-masing obyek.

6.Menarik kesimpulan dari analisis untuk dijadikan sebagai guidelines melihat aplikasinya dalam desain.

\section{HASIL DAN PEMBAHASAN \\ Teori}

“Delirious New York", penggunaan kata "delirious" sendiri memiliki arti ganda, yaitu sangat gembira hingga lupa daratan dan mengigau karena demam. (Oxford, 2003). Buku ini menyajikan analisis Koolhaas terhadap Manhattan. Menghadirkan beberapa kesimpulan mengenai "Nature of the city" hingga "Culture of Congestion" sebagai manifesto Manhattanism. Buku ini juga sedikit menceritakan pemikiran dasar mengenai Bigness, Three axioms, Generic city, dan Pragmatic Camouflage. Pemikiran-pemikiran dasar ini yang akhirnya muncul dalam buku-buku Koolhaas yang lain.

“ $S, \boldsymbol{M}, \boldsymbol{L}, \boldsymbol{X L}$, , merupakan judul buku kedua Koolhaas. Buku ini banyak berisi mengenai beberapa proyek Koolhaas yang dibagi berdasarkan skala. Masing-masing proyek menggambarkan pemikiran Koolhaas, antara lain mengenai program-free program space, strategy of the void, organization of appearance, congestion without manner. Terselip di antara proyek-proyek tersebut juga terdapat berbagai esai, di antaranya Imagining nothingness, Globalization, Manifesto = Bigness, Singapore dan Generic city. Judul yang digunakan sengaja untuk menampilkan bagaimana masa depan dapat dibentuk melalui sesuatu yang 
diciptakan di masa lalu, sebuah standar ukuran. Pemikiran-pemikiran pokok yang muncul dari karya ini adalah mengenai "Bigness", yaitu pada skala besar tertentu, bangunan tidak lagi tunduk pada prinsip-prinsip estetika klasik (komposisi, skala, proporsi, detail). Hal lain yang muncul juga dalam buku ini adalah "Generic city", yaitu konsep Koolhaas yang menyatakan bahwa kemajuan, identitas, arsitektur, kota dan jalan adalah sesuatu dari masa lalu: "Relief ... it's over... masa depan dapat dibentuk melalui sesuatu yang diciptakan di masa lalu, misalnya: sebuah standar ukuran.

"Project on the City", merupakan karya dan penelitian Koolhaas selama menjadi Profesor di Harvard Design School. Proyek ini melibatkan beberapa mahasiswanya. Terdapat beberapa buku yang berhasil diterbitkan, antara lain: "Muttation" (2001), "The Harvard Design School Guide to Shopping" (2002) dan "The Great Leap Forward" (2002). Buku-buku tersebut berisi kritik Koolhaas, menjadikannya sinis (cynical), seolah-olah Barat dengan kapitalisme dan globalisasi memusnahkan semua identitas budaya - Gagasan dalam buku ini bahwa "In the end, there will be little else for us to do but shop". Namun, jika begitu sinisme dapat dibaca sebagai "realisme" tentang transformasi kehidupan budaya. Sebuah bangunan landmark seharusnya tidak hanya menjadi "intelectual comfort” saja, atau karena kekuasaan pemerintah tapi harus bisa dinikmati oleh masyarakat umum

“Content" (2003), lebih merupakan sebuah dialog, bagaimana Koolhaas dan orang-orang yang bekerja di OMA menggambarkan OMA sendiri. Hasilnya adalah sebuah "branding" OMA kepada publik. Melalui bentuk informasi gambar dan teks yang padat, buku ini menegaskan pernyataan Koolhaas "Never mind the style... Feel the quality” (Koolhaas, 2003). Dengan keanekaragaman bentuk penyampaian informasinya, buku ini justru mampu menggambarkan bagaimana pemikiran-pemikiran Koolhaas pada buku-buku sebelumnya menjadi prinsip yang sama bagi Koolhaas dan semua orang di OMA dalam berkarya. Bila dirunut lebih jauh, kata "... the quality" dalam pernyataan Koolhaas di atas dapat diartikan pula sebagai “... the content", yang juga menjadi judul buku ini. Beberapa kritik terhadap buku ini memunculkan sebutan baru bagi Koolhaas sebagai "Master of Camouflage". Istilah "camouflage" sendiri muncul dalam buku pertamanya, "Delirious New York". "I am business; I am Profit and Loss; I am Beauty come into the Hell of the Practical" (Casseres dalam Koolhaas, 1978). Sebuah puisi karya Casseres yang dikutip Koolhaas untuk menggambarkan bagaimana bisnis mampu melebur dalam bangunan melalui keindahan, sebuah pragmatic camouflage. Koolhaas sendiri memasukkan dan melakukan kamuflase terhadap"prinsip-prinsip pemikirannya" dalam desain, "content camouflage".

\section{Metoda}

Dalam berbagai essai, wawancara, dan buku Koolhaas, tidak terdapat satupun pernyataan eksplisit mengenai metoda yang digunakan. Bila hal ini dikembalikan pada pernyataan, "Nevermind the style... Feel the quality" (Koolhaas, 2003), pernyataan Koolhaas tersebut sebenarnya memiliki makna luas. Bila Koolhaas mampu melakukan kamuflase pada tingkat kompleks, pernyataan ini juga dapat "dipermainkan" menjadi, "Feel the content... Nevermind the method".

Lepas dari pernyataan di atas, metoda yang banyak digunakan Koolhaas juga dapat disarikan dari penggunaan beberapa istilah dan kalimat dalam essai, wawancara serta bukunya. Beberapa yang akhirnya cukup kuat untuk dipaparkan sebagai metoda Koolhaas adalah:

Augmented space, melalui metoda ini content (pemikiran Koolhaas) terkamuflasekan dengan cara mengisi ruang-ruang (fisik) dengan permainan data dan informasi. Hal ini memanfaatkan sekaligus merupakan kritik terhadap budaya konsumsi symbol masyarakat perkotaan. Augmented space sendiri merupakan istilah dari kritikus. Namun secara implisit dapat ditemukan pada buku $S, M, L, X L$ (1995) pada bagian L. Terdapat pembahasan mengenai 
"strategy of the void" yang dapat disetarakan dengan strategi "information surface" milik Robert Venturi.

Cross programming, melalui metoda ini Dualisme/Ambiguity terbentuk dengan cara menggabungkan fungsi-fungsi umum dengan program-program ruang yang bersifat formal. Istilah cross programming pertama kali muncul pada buku pertama Koolhaas, Delirious New York (1978). Hal ini diperkuat pada buku $S, M$, L, XL (1995). bagian XL.

Programmed-free programmed space, melalui metoda ini content (pemikiran Kool-haas) terkamuflasekan dengan cara meletakkan ruangruang terprogram melayang di antara ruang-ruang bebas/ fleksibel yang tidak ter-program. Istilah "program-free program" mun-cul pada buku pertama, Delirious New York (1978).

Deconstructions, melalui metode ini sifat dualisme Koolhas sangat terlihat dalam melihat konsep Generic City yang teratur dibandingkan dengan konsep Bigness yang tidak mempunyai aturan apapun (anti Sintesis, anti Fungsional, anti Order).

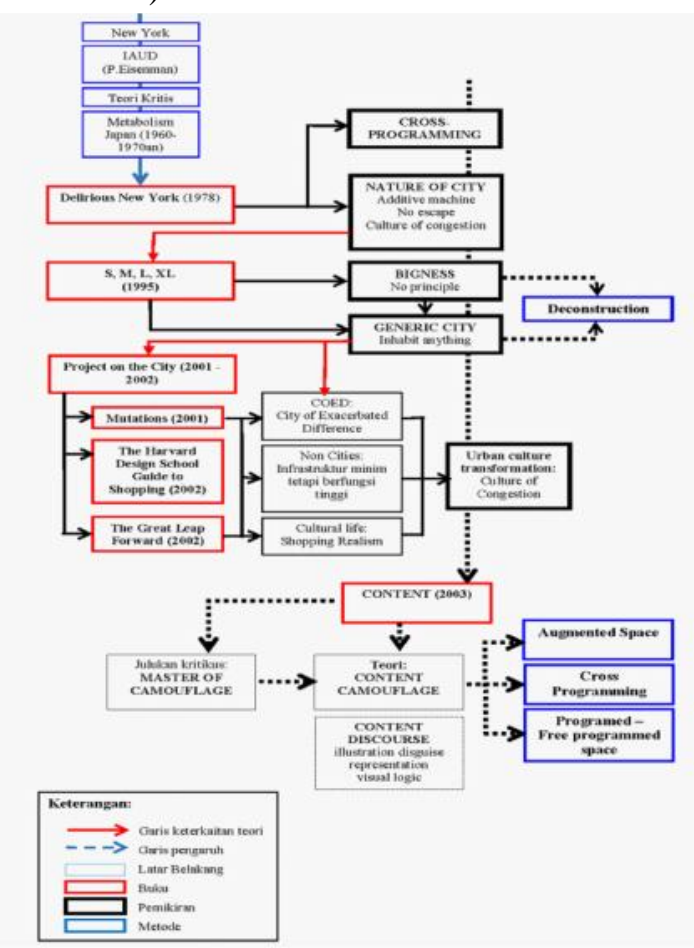

Gambar 1. Alur Pemikiran, Teori dan Metode Desain Remment Koolhas
Keterkaitan pemikiran dan minat dari buku pertama Delirious New York hingga era Project on the City menunjukkan adanya konsistensi teori di balik itu. Sebuah teori yang terus dikembangkan, dan pada saat yang bersamaan menjadi eksperimen (aplikasi) dalam proyekproyek desainnya.

Bermula dari manifesto Manhattanism pada Delirious New York, Koolhaas mengungkapkan pemikiran-pemikirannya mengenai Nature of the City, Culture of Congestion hingga crossprogramming. Beberapa karya desain lahir dengan dasar pemikiran ini. Berlanjut pada $S$, $M, L, X L$ dengan pemikiran mengenai Bigness dan Generic city. Dua pemikiran yang jelas-jelas merupakan kelanjutan dari buku sebelumnya. Project on the City merupakan penghalusan dari pemikiran-pemikiran Koolhaas sebelumnya. Membahas mengenai fenomena dan realita yang terjadi. Menggunakan contoh-contoh nyata yang semakin membentangkan pengaruh pemikiranpemikiran Koolhaas pada negara dunia Ketiga. Dari berbagai pemikiran Koolhaas dalam diagram sebelumnya (lihat Grafik 1), terlihat adanya alur teori yang melandasi bagaimana pemikiran satu dan yang lain saling berkaitan. Teori tersebut seolah terjawab pada judul buku terakhir Koolhaas , Content (2003). Buku ini menggambarkan bagaimana pemikiranpemikiran Koolhaas, yang muncul pada buku sebelumnya, berubah menjadi prinsip-prinsip berfikir dan desain bagi Koolhaas dan OMA, maupun AMO. Kritik yang muncul terhadap buku ini menghadirkan julukan lain kepada Koolhaas, "Master of Camouflage". Satu pernyataan Koolhaas yang menjadi kunci buku ini adalah, "Nevermind the style... Feel the quality" (Koolhaas, 2003). Koolhaas tidak peduli muncul dengan gaya apa, namun kualitas dari desain merupakan sebuah harga mati. Pernyataan itu sendiri dapat diterjemahkan beragam. "Kualitas" dalam kalimat tersebut dapat berarti "Content", sebagaimana judul dari buku itu sendiri. Sedangkan "gaya" dalam kalimat tersebut dapat berarti "metoda". Bila disusun kembali, pernyataan tersebut menjadi, "Feel the Content... Nevermind the Method". 


\section{Aplikasi}

Beberapa karya desain yang dapat menunjukkan bagaimana teori Koolhaas mengenai content dapat terkamuflasekan dalam desain melalui empat metoda, yang telah disebutkan di atas. Antara lain adalah :

\section{Kunsthal, Rotterdam (1992)}

Bangunan Kunsthal merupakan sebuah galeri seni yang cukup menarik karena desain Koolhas ini melibatkan 1 (satu) sirkulasi internal galeri dan 2 (dua) jenis sirkulasi luar (publik) yang menembus melewati bangunan itu sendiri. Sebuah jalan bagi kendaraan dibuat menembus bagian bawah bangunan. Sedangkan sirkulasi pejalan kaki dapat menembus bangunan tanpa mengganggu sirkulasi internal galeri tersebut. Penggunaan material transparan membuat ketiga jenis sirkulasi yang ada, mampu terpisah namun tetap terintegrasi secara dinamis.

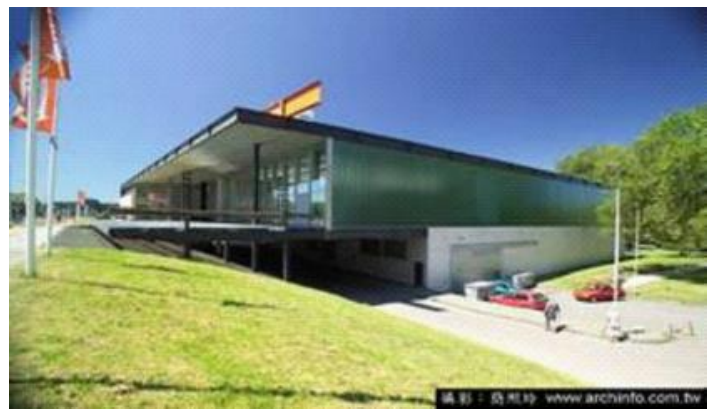

Gambar 2. Kunsthal, Rotterdam (1992)

\section{Euralille (1994)}

Euralille merupakan proyek OMA, antara tahun 1990-1994, yang mendahului diterbitkannya buku S, M, L, XL, tahun 1995. Euralille justru memperkenalkan salah satu pemikiran Koolhaas mengenai Bigness sebelum akhirnya dituliskan pada buku S, M, L, XL pada tahun berikutnya. Meski demikian dasar pemikiran ini sudah muncul pada buku “Delirious New York". Pernyataan Koolhaas (1978) ini muncul setelah mempelajari kota Manhattan, “... such structures can devote their exteriors only to formalism and their interiors only to functionalism". Desain
Euralille ini menjadi contoh aplikasi Bigness yang dimaksud Koolhaas.

Pada desain ini Koolhaas berperan sebagai Masterplanner yang membawahi belasan arsitek lain. Koolhaas secara khusus melakukan desain terhadap pergerakan (terutama) pada lantai dasar kompleks tersebut, namun memberi kebebasan desain untuk eksterior dan lantai-lantai berikutnya pada masing-masing arsitek.

Dengan demikian, dari luar kita ,dapat melihat perbedaan desain yang ditampilkan Jean Nouvel pada satu sisi kompleks, dan Koolhaas sendiri pada sisi yang lain. Namun saat kita memasuki bangunan tersebut, seluruh bagian kompleks merupakan sebuah sistem yang terintegrasi dan berfungsi optimal.

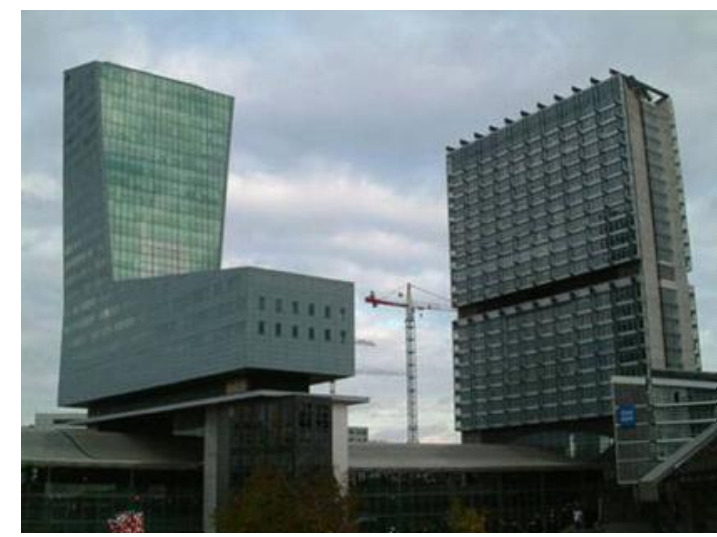

Gambar 3. Euralille (1994)

\section{Prada Epicenter, New York (2001)}

Proses kamuflase di desain Prada Epicentrum ini terjadi pada bagaimana ruang-ruang di sini berdialog dengan pengunjung toko. Hal-hal yang bersifat informasional dari merek "Prada" tersampaikan kepada pengunjung, melalui pengalaman ruang yang terjadi. Informasi pertama yang ingin disampaikan adalah toko ini merupakan panggung teater/ catwalk bagi para pengunjung toko itu sendiri. Antara pengunjung satu dengan yang lain dapat saling melihat pakaian dan model yang dikenakan, sehingga menegaskan bahwa "Prada" bukan menjual barang tetapi menjual merek (lihat poin a, grafik 3). 


\section{5 | JUTEKS Jurnal Teknik Sipil Volume 2 Nomor 2 Oktober 2017}

Informasi kedua kembali menegaskan bahwa "Prada" sebagai merek merupakan (semacam) religi baru bagi masyarakat kota. Penyajian icon-icon "Prada" pada toko ini menyerupai penyajian gambar-gambar orang suci di gereja. (lihat poin b, grafik 3). Pada bagian lain juga terdapat peta dunia yang dilengkapi titik-titik toko "Prada" sebagai gambaran cakupan/persebaran religi baru tersebut.

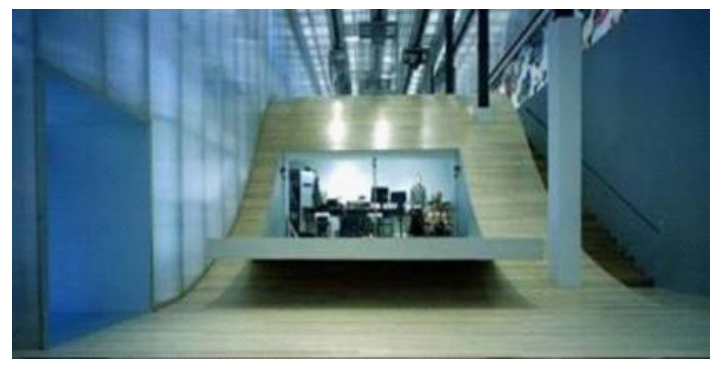

Gambar 4. Prada Epicenter, New York (2001)

\section{CCTV, Beijing (2002)}

CCTV Beijing merupakan salah satu proyek Koolhaas yang sedang dibangun pada saat tulisan ini dibuat. Bangunan ini dibangun dalam rangka menyambut kegiatan Olimpiade 2008 Beijing. Sehingga selain berfungsi sebagai gedung penyiaran, fungsi "prestige" monumental juga menjadi penting untuk promosi Cina. Prinsip-prinsip bangunan menumental konvensional ternyata mengalami interpretasi ulang saat Koolhaas justru meletakkan bagian "void" di tengah dan dikelilingi bagian "solid" (monumennya). Koolhaas menggunakan lokasi void tersebut sebagai jalur sirkulasi bebas yang dengan sengaja memotong site bangunan, hal yang tidak ditemui pada prinsip bangunan monumental konvensional. Cross programming melalui cara memasukkan fungsi sirkulasi bebas di tengah monumen memberi interpretasi dan cara melihat bangunan monumental yang baru.

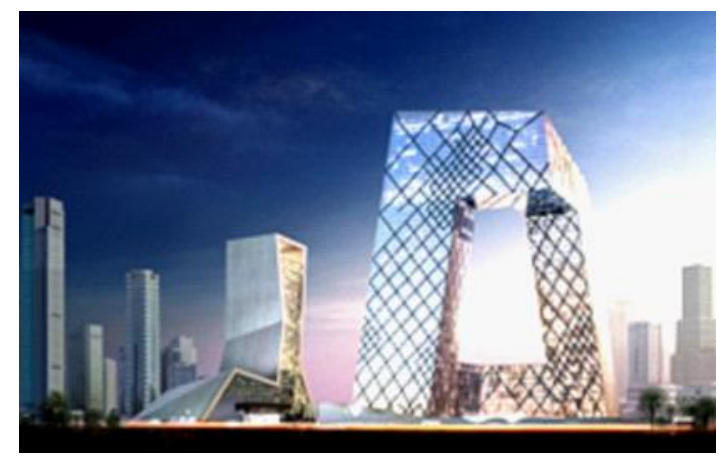

Gambar 5. CCTV, Beijing (2002)

\section{Seattle Central Library (2004)}

Seattle Central Library juga dapat digunakan untuk menjelaskan metoda ketiga Koolhaas. Pada bangunan Seattle Central Library dapat kita lihat bagaimana fungsi perpustakaan ditransformasikan dalam bentuk sirkulasi sirkular dan linear. Fungsi utama bangunan ini adalah fungsi terkontrol (programmed), yaitu rak-rak buku yang tertata sepanjang sirkulasi perpustakaan. Ruang-ruang lain yang terdapat pada bangunan ini bersifat lebih fleksibel, berupa ruang-ruang terbuka bebas (open plan). Pada bangunan ini juga terlihat jalurjalur sirkulasi luar umum yang dibiarkan menembus pada lantai dasarnya.

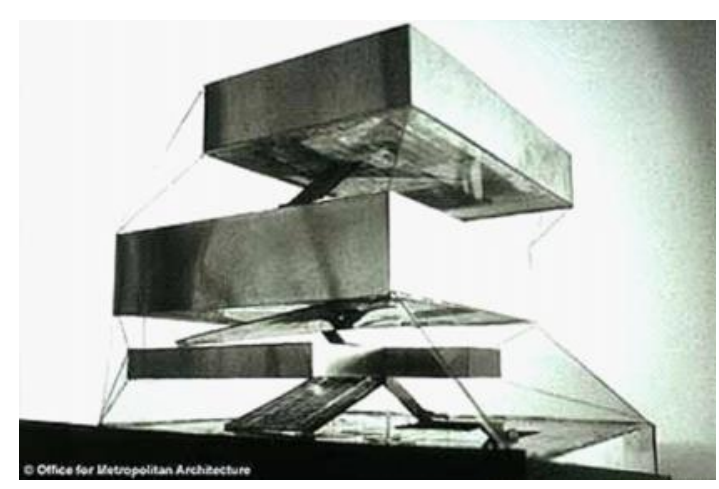

Gambar 6. Seattle Central Library (2004)

\section{Seoul National University (2005)}

Seoul National University adalah contoh ekstrim dimana program baru yang ditawarkan Koolhaas diangkat dan dibenamkan untuk menjaga ruang sirkulasi pada lantai dasarnya. 
Fungsi auditorium diangkat ke lantai 2 (dua) dan fungsi perpustakaan dibenamkan ke lantai basement. Lantai dasar hanya sebagai entrance dan sirkulasi. Ini menunjukkan konsistensi Koolhaas dalam menjaga ruangruang yang bebas dari kontrol (freeprogrammed) dan ruang-ruang yang perlu terkontrol (programmed).

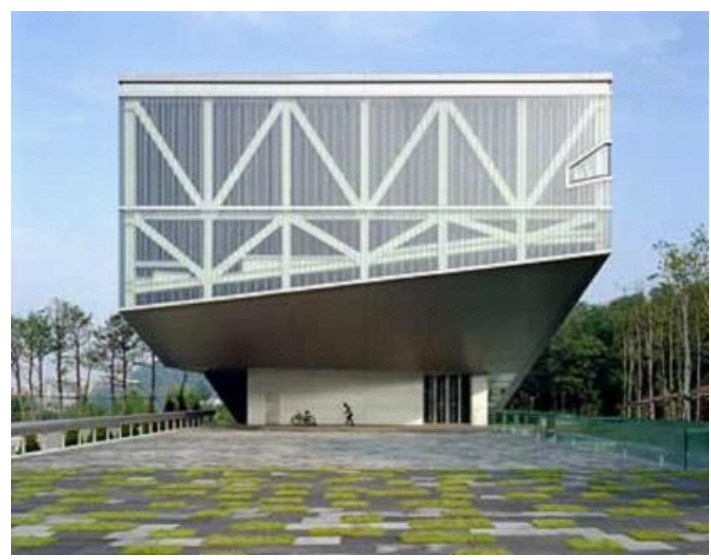

Gambar 6. Seoul National University (2005)

\section{KESIMPULAN}

Latarbelakang kehidupan Koolhaas nampaknya berperan besar dalam membentuk pola berfikirnya. Tumbuh di tengah pergolakan dunia dan persentuhannya dengan jurnalisme gerakan kiri dari ayahnya membentuk Koolhaas sebagai seorang yang cynical, keras dan selalu berlari dalam fikirannya sendiri. Pertemuannya dengan tokoh-tokoh critical architecture memberi warna rasional kritis dalam setiap karya tulis maupun desainnya. Di sisi lain Koolhaas mengalami kehidupan sebagai orang Asia dan hidup di dunia seni budaya serta dunia peran. Dari sisi ini Koolhaas menemukan bentuk terluar untuk karya-karyanya, kulit, peran serta kamuflase.

Koolhaas mengawali semua perjalanan pemikirannya dari buku pertamanya, Delirious New York. Buku pertama ini menjadi pijakan Koolhaas untuk pemikiran-pemikiran selanjutnya. Koolhaas merupakan salah satu arsitek yang sangat intens mengamati budaya masyarakat perkotaan, terutama fenomena density di masyarakat. Istilah Koolhaas untuk fenomena ini adalah "culture of congestion" yang dalam terjemahan bebasnya menjadi "budaya berpadat-padatan". Arsitek lain yang juga intens dengan fenomena density ini adalah Bernard Tschumi. Kompetisi desain "Parc de la Villette" memutuskan desain Koolhaas dan desain Tschumi sebagai pemenang bersama, meski desain Koolhaas akhirnya tidak terbangun. Kompetisi ini memperlihat bahwa keduanya mengangkat isu yang sama, density, meski keduanya menyelesaikan dengan cara yang berbeda.

Tidak bisa lepas dari berbagai pemikiran Koolhaas yang lain, bigness, generic city dan program, apa yang sebenarnya ditawarkan oleh Koolhaas adalah pendekatan-pendekatan kritis terhadap isu-isu budaya masyarakat kota. Pendekatan kritis Koolhaas tersebut muncul di berbagai desainnya, dalam bentuk terselubung, terkamuflasekan. Dengan demikian, di balik selubung keindahan desain Koolhaas terdapat kritik terhadap masyarakat kota itu sendiri

\section{DAFTAR PUSTAKA}

Guardian,2006,http://arts.guardian.co.uk/ features/story $/ 0 . .1803857,00 . \mathrm{html}, 06 \mathrm{Maret}$ 2017.

Harisah, Afifah. 2005. Ekletisme dan Gaya Arsitektur Ekletik di Amerika Serikat: Kajian Konsep dan Prinsip-prinsip Perancangan. Tesis Jurusan Arsitektur UGM Jogyakarta.

Koolhaas, Rem, 1978, 1994, Delirious New York, The Monacelli Press, New York.

Koolhaas, Rem dan Mau, Bruce, 1995, S, M, L, $\boldsymbol{X} \boldsymbol{L}$, Monacelli Press, New York.

Koolhaas, Rem, 2001, Mutations (Project on the City), Harvard Design School

Koolhaas, Rem, 2002, Great Leap Forward (Project on the City), Harvard Design School. 
207 JUTEKS Jurnal Teknik Sipil Volume 2 Nomor 2 Oktober 2017

Koolhaas, Rem, 2002, Harvard Design School Wired, 1996, Interview 4 July 2007, http:// Guide to Shopping (Project on the City), Harvard Design School.

www.wired.com/wired/archive/4.07/ koolhaas.html, 06 Maret 2017.

Muhadjir, H. Noeng, 1998. Metodologi Penelitian Kualitatif, Rake Sarasin, Yogyakarta. 